\title{
家畜精液の液状および凍結保存に関する研究
}

\section{III. 山羊凍結精子の生存性および受胎力}

\author{
和出 靖 - 丹羽太左衛門* ・浅沼良吉** \\ (農林省畜産試験場・岩手大学農学部* ・群馬県畜産試験場**)
}

山羊精液の凍結保存については, LIESS \& OSTROW$\mathrm{SKI}^{1)}$, 和出䚾か ${ }^{2,3)}$, WAIDE \& NIWA ${ }^{4)}$, FrASER $^{\text {(5), }}$, VLACHOS \& TSAKLOV ${ }^{8)}$, BONFERT ${ }^{7)}$ およびその他の研 究者よって報告されているが，牛および羊精子の凍結に ついての報告に比べるとその数は多くない。本実験で は, 山羊凍結精子の生存に及ぼす希釈液中の卵黄量, グ リセリン濃度, グリセリン平衡時間, 希釈倍率, 精液容 器と凍結方法などの各種要因について検討し, 著者らが 開発した山羊精液凍結用の希釈液 ECSD (Table 1) によ る凍結精液を用いて受胎試験を行い, 凍結精子の受胎力 および山羊凍結精液による実用的な人工授精の可能性に ついて検討した。

\section{実験材料および方法}

\section{I. 凍結精子の生存性}

ザーネン種 15 頭から 11 3 月に採取した 146 例の 精液を用いた。採取精液は $25 \sim 27^{\circ} \mathrm{C}$ 温度条件を保つよ らにして数頭分の精液を混合し, 精子活力の検査後, 精 子生存率および活力が良好で精液の $\mathrm{pH}$ が正常な範囲の ものについて, 採取後約 10 分以内に実験区分に従って 以下のように処理凍結し, 精子生存性を検討した。緩徐 凍結では，実験目的に従った第 1 次希秎液（A）により $25 \sim 27^{\circ} \mathrm{C}$ の等温条件で 5 倍に希釈（第 1 次希釈）した のち, 約 70 分で $4^{\circ} \mathrm{C}$ に精液温度を緩徐に下降させた。 第 1 次希釈 $3 \sim 4$ 時間後に, 必要に応じて第 1 次希釈液

Studies on preservation of liquid and frozen semen of domestic animals. III. Viability and fertility of frozen goat spermatozoa.

WAIDE, Yasushi (National Institute of animal Industry, Chiba-shi, 280), Tazaemon Niwa (Department of Animal Sience, Iwate University, Morioka) and Ryōkichi Asanuma (Gunma Prefectural Livestock Experimental Station, Gunma-ken)

Japan. J. Anim. Reprod. 23 (4), 1977.
により $4^{\circ} \mathrm{C}$ の等温条件で再希瀵を行い，ついでグリセ リンを含有した第 2 次希釈液 (B) により等量の最終希 釈を行った。最終希釈は， 15 分間隔で 4 回に分け $1 / 10$, $2 / 10,3 / 10$ および $4 / 10$ 容量の割合で第 2 次希釈液を添 加混合した。 $4^{\circ} \mathrm{C}$ で 6 18 時間のグリセリン平衡後, $1 \mathrm{ml}$ 容量のアンプル内に希釈精液を $0.5 \mathrm{ml}$ ずつ分注し て密封し，ドライアイスとアルコールを用いて $-79^{\circ} \mathrm{C}$ に冷却し凍結した。温度下降速度は， $4^{\circ} \mathrm{C}$ から $-15^{\circ} \mathrm{C}$ までを 1 分間に約 $1^{\circ} \mathrm{C},-15^{\circ} \mathrm{C}$ から $-30^{\circ} \mathrm{C}$ までを毎分 $4 \sim 5^{\circ} \mathrm{C},-30^{\circ} \mathrm{C}$ から $-75^{\circ} \mathrm{C}$ までを毎分 $3 \sim 4^{\circ} \mathrm{C}$ の速度 で下降させた。アンプルによる凍結では， $-75^{\circ} \mathrm{C}$ に精 液温度が下降後, $-79 \sim-80^{\circ} \mathrm{C}$ の電気的超低温槽 (ア ルコール槽) 中に精液を移して保管するか，または液体 窒素中に移して $-196^{\circ} \mathrm{C}$ に保管した。ストローによる 急速凍結では， $0.5 \mathrm{ml}$ の細型ストローにグリセリン平 衡後の精液を約 $0.45 \mathrm{ml}$ ずつ分注して閉封後, 液体窒 素蒸気によって $4^{\circ} \mathrm{C}$ から $-40^{\circ} \mathrm{C}$ までを約 $3 \sim 4$ 分, $-100^{\circ} \mathrm{C}$ までを約 $5 \sim 6$ 分の速度で急速に温度を下降さ せて凍結した。精液温度が $-130^{\circ} \mathrm{C}$ 以下に下降後, ス トローを液体窒素中へ移して $-196^{\circ} \mathrm{C}$ に保管した。精 液は凍結前と凍結直後に精子の活力検査を行ったが，精 液の融解は $20^{\circ} \mathrm{C}$ の水中にアンプルまたはストローを浸 漬して融解し, 融解後直ちに常法の活力検査によって精 子の生存率および運動性を検査した。

実験 1. 希釈液中の卵黄量が凍結・融解後の精子生存 性に及ぼす影響：希釈液中の卵黄量と凍結精子の生存性 との関係を知る目的で，10\%，15\%，20\%，25\%，30\% および $40 \%$ の卵黄量を含有した卵黄クエン酸ナトリウ 么液 (以下 ECD と略称, 第 2 次希釈液 (B液) 中に 14\%のグリセリンを含有, Table 1) によって最終希釈 倍率を 10 倍とし, $0.5 \mathrm{ml}$ ずつアンプルに 分注後緩徐 凍結した。凍結後直ちに $20^{\circ} \mathrm{C}$ の水中で融解して, 凍 結・融解後の精子生存性を常法の活力検査により検討し 
た。

実験 2. 希釈液中のグリセリン濃度が凍結・融解後の 精子生存性に及ぼす影響：卵黄量を $20 \%$ とした ECD を用い, 第 2 次希釈液 (B液) 中のグリセリン濃度を, それぞれ希釈後の希釈精液中における最終濃度におい て, 3\%, 5\%, 6\%, 7\%,8\%, 9\%, 10\%, 11\%, 13\% および $15 \%$ になるようにし，アンプルによる緩徐凍結 により凍結してグリ七リン濃度と凍結・融解後の精子生 存性との関係を検討した。

実験 3. グリセリン平衡時間が凍結・融解後の精子生 存性に及ぼす影響：著者らが山羊精子の凍結用希釈液と して開発した下記組成の ECSD 液 (Table 1) で 10 倍 に希釈した精液を， 1.5 時間， 3 時間，6 時間， 12 時 間, 18 時間, 24 時間および 48 時間のグリセリン平衡 ののちに，アンプルによる緩徐凍結によって凍結し，グ リセリン平衡時間と精子生存性との関係を検討した。

実験 4. 希釈液の組成が凍結・融解後の精子生存性に 及ぼす影響: ECD, ECGD, ECSD, ECED および ECPD の 5 種類の希釈液 (Table 1) により精液を 10 倍に希 釈し,グリセリン平衡後アンプルによる緩徐凍結によっ て凍結し, 凍結・融解後の精子生存性におよぼす希釈液 の影響について検討した。

実験 5. 希釈倍率が凍結・融解後の精子生存性に及法 寸影響: ECSD, ECGD, ECD の 3 種類の希釈液を用い て, 同一精液を 10 倍, 20 倍, 30 倍および 40 倍に希 釈して, アンプルによる緩徐凍結によって凍結し, 各希 积液の精子生存性に及ぼす影響を検討した。

実験 6. 融解温度が凍結・融解後の精子生存性に及泣 す影響: 希棌液として ECSD を用い, アンプルにより 緩徐凍結した精液を, $5^{\circ} \mathrm{C}, 10^{\circ} \mathrm{C}, 15^{\circ} \mathrm{C}, 20^{\circ} \mathrm{C}, 25^{\circ} \mathrm{C}$, $30^{\circ} \mathrm{C}, 40^{\circ} \mathrm{C}$ および $50^{\circ} \mathrm{C}$ の各温度の水または温水中に アンプルを浸漬して融解し, それぞれ融解後直ちに取出 して精子の活力検査を行い融解温度の影響を検討した。

実験 7. ストローによる急速凍結が凍結・融解後の精 子生存性に及ぼす影響：ECSD により 10 倍に希釈した 同一精液を，グリセリン平衡後に $0.5 \mathrm{ml}$ ストローおよ び $1 \mathrm{ml}$ アンプル内にそれぞれ $0.45 \mathrm{ml}$ ずつ分注して 閉封し, ストローは急速凍結器を用いて上記の温度下降 速度で液体窒素蒸気により急速に凍結した。アンプル内 分注精液は緩徐凍結により凍結した。各凍結精液は凍結 終了後直ちに $20^{\circ} \mathrm{C}$ の水中で融解し, 常法による精子活 力検查を行ってそれぞれの精子生存性を比較検討した。

\section{II. 凍結精子の受胎力}

受胎試験に使用した精液は，上記の種雄山羊から採取
した精液を，ペニシリンおよびストレプトマイシンを希 釈液 $1 \mathrm{ml}$ 当たりそれぞれ 900 単位および $900 \mu \mathrm{g}$ の割 合に添加した ECSD-A 液 (第 1 次希釈液)により，25〜 $27^{\circ} \mathrm{C}$ の等温条件で 5 倍 $(1: 4)$ に第 1 次希釈を行い, 約 1.5 時間かけて緩徐に $4^{\circ} \mathrm{C}$ に精液温度を冷却し, 第 1 次 希釈から $3 \sim 6$ 時間後に, $4^{\circ} \mathrm{C} に$ おいて必要に応じ ECSD-A 液による再希釈と ECSD-B 液（第 2 次希釈 液, $\mathrm{A}$ 液と同量の抗生物質含有）による最終希釈（上記 のような分割希釈による）を行い，6〜18 時間のダリセ リン平衡後に $0.5 \mathrm{ml}$ ずつ $1 \mathrm{ml}$ アンプル内に分注して 緩徐凍結により凍結した。当場（農林省畜産試験場）で の受胎試験は, 当場における採取精液を凍結して保管 し, 必要に応じて $20^{\circ} \mathrm{C}$ で融解して授精した。群馬県畜 産試験場での野外受胎試験は, 同場の種雄山羊から採取 した精液を ECSD-A 液で第 1 次希釈後に当場 (千葉) 一輸送し，当場において最終希釈と凍結を行い，群馬県 畜産試験場へ凍結後の精液を送り返して保管と授精を行 った。

なお，受胎試験の当初において従来山羊凍結精液の受 胎率が低い1) とされている原因についての検討を行い， 精液注入部位を従来の子宮頸管外口部から深部注入に改 める目的で山羊用の子宮頸管鉗子と深部注入用ピペット を考案して，子宮頸管内深部へ注入することにより受胎 率の向上をはかった4)。授精は発情山羊の授精適期に， 頸管内深部注入法により $0.5 \mathrm{ml}$ の精液を 1 発情 1 回注 入した。授精に使用した精液の希釈倍率は 10 30 倍で ある。

\section{実験結果}

\section{I. 凍結精子の生存性}

1. 卵黄濃度と生存性：希釈液中の 卵黄量を 10 40\%として, 卵黄量と精子生存性の関係を検討した結 果, 卵黄量 $10 \%$ および $15 \%$ では凍結・融解後の精子 生存率が平均 $50 \%$ 以下で，卵黄量 $20 \%$ および $25 \%$ の場合に比べて劣る結果を得た。即黄量 $20 \%$ では融解 後の精子生存率平均 $55.3 \%$ の最高値を示した。卯黄量 $25 \%$ の場合は $20 \%$ に比べてやや低い精子生存性が得 られたが有意差がなく, 凍結・融解後の精子生存性に与 える影響としては両者とも同程度であった。卵黄量 $30 \%$ では $15 \%$ の場合にほぼ相当し，40\% では 20 $25 \%$ の場合に比べ有意差（P. 0.01）をもって極端に精 子生存率が低下し, 精子運動性も低下することが認めら れた。従って上記の結果から，山羊精液の凍結に卵黄緩 衝液を用いる場合の, 卵黄量の最適濃度は 20 25\% で 


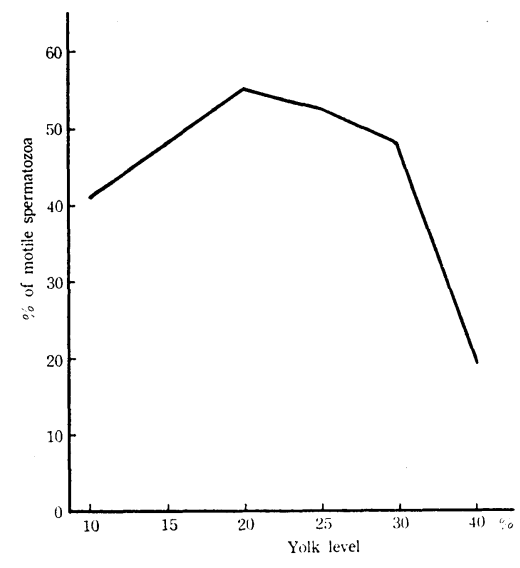

Fig. 1. Effect of egg yolk level on the percentage of motile spermatozoa after freeze-thawing.

あることを認めた (Fig. 1)。

2. グリセリン濃度と生存性：希釈精液中の最終グリ セリン濃度が, 凍結・融解後の精子生存性に及泟す影響 について検討した結果，グリセリン濃度 $3 \%$ では融解 後の精子生存率が低く平均 $23.5 \%$ の生存率であった が， $5 \%$ の濃度では精子生存率が良好となり平均 $48.2 \%$ を示した。グリセリン濃度 6 10\% 間では，いずれる 融解後の精子生存率に打いて $50 \%$ 以上を示し良好な結 果を得たが，7\% および $8 \%$ にお拈る精子生存率が最 も良好で，希釈精液中の グリセリン最終濃度は 7 8\% が山羊凍結精液において最適範囲であることを認めた。 $11 \%$ 以上では融解後の精子生存率を低下させ，13\% で は生存率 $20 \%$ 以下，15\% では生存率 $10 \%$ 以下と極 端に生存率が低下した (Fig. 2)。

3. グリセリン平衡時間と生存性： ECSD で 10 倍に 希釈した同一精液について，グリセリン平衡時間と凍 結・融解後の精子生存性との関係を検討した 結果, 1.5 時間の平衡時間においても比較的良好な精子生存性が得 られたが， 3 時間および 6 時間と平衡時間を延長するに 伴って凍結後の精子生存率が漸次向上した。グリセリン 平衡 6 18 時間では精子生存率に注とんど差がなく良好 な結果が得られ，融解後の精子生存率はそれぞれ平均 $55 \%$ 以上を示したが，24 時間以上の平衡では漸次生存 率が低下した。以上の結果から，山羊精液の凍結におい ては 6 18 時間が最適グリセリン平衡時間であることを 認めた (Fig. 3)。

4. 希釈液の組成と生存性：希釈液の組成 (Table 1) と凍結・融解後の精子生存性について検討した結果は,

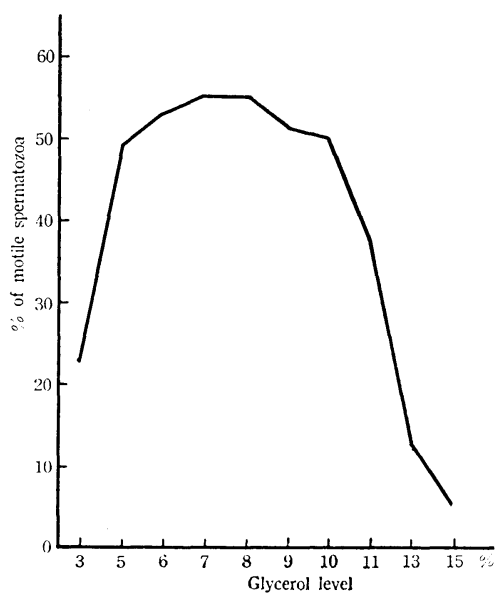

Fig. 2. Effect of glycerol level on the percentage of motile spermatozoa after freeze-thawing.

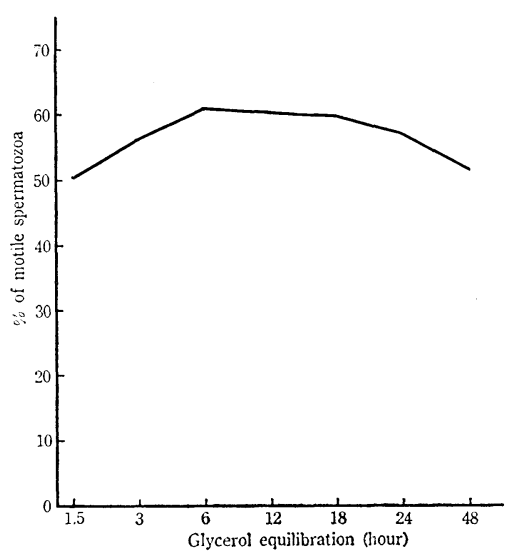

Fig. 3. Effect of glycerol equilibration time on the percentage of motile spermatozoa after freeze-thawing.

ECD に比べ桾類としてグルコースを含有した ECGD が ややまさり, 前 2 者に比べ著者らの開発した ECSD が 著差はないが最も良好な精子生存率と活力を示した。グ リセリンの代わりに抗凍結物質としてェチレングリコー ルおよびプロピレングリコールを含有した ECED およ び ECPD によるものは，極めて不良な結果を示し，両 者とも凍結・融解後の 精子生存率が $5 \%$ 以下となり, 精子運動性も低下した (Fig. 4)。

5. 希釈倍率と生存性: 10 倍, 20 倍, 30 倍および 40 倍の希釈倍率が，凍結後の精子生存性に及洔す影響 そついて検討した結果は，ECSD， ECGD および ECD による 3 種類の希釈精液とも 10 倍抢よび 20 倍では大 
Table 1. Composition of the diluents, $A$ and $B$

\begin{tabular}{|c|c|c|c|c|c|c|c|c|c|c|}
\hline \multirow{2}{*}{$\begin{array}{l}\text { Ingredients }^{\mathrm{a})} \\
\quad(\mathrm{g} / 100 \mathrm{ml})\end{array}$} & \multicolumn{5}{|c|}{ Diluent A } & \multicolumn{5}{|c|}{ Diluent B } \\
\hline & ECSD & ECD & ECGD & ECED & ECPD & ECSD & ECD & ECGD & ECED & ECPD \\
\hline Sodium citrate & 1.92 & 2.4 & 1.92 & 2.4 & 2.4 & 1.73 & 2.4 & 1.92 & 2.4 & 2.4 \\
\hline Glucose & 1.17 & - & 1.12 & - & - & 0.42 & - & 1.12 & - & - \\
\hline Glycocoll & 0.17 & - & - & - & - & 0.07 & - & - & - & - \\
\hline $\begin{array}{l}\text { Sodium phosphate dibasic } 12 \\
\text { hydrate }\end{array}$ & 0.08 & - & - & - & - & - & - & - & - & - \\
\hline Citric acid & 0.004 & - & - & - & - & 0.003 & - & - & - & 一 \\
\hline Chlorpromazine & 0.003 & - & - & - & - & 0.002 & - & - & - & - \\
\hline Glycerol (v/v\%) & 一 & - & - & - & - & 14.00 & 14.00 & 14.00 & - & - \\
\hline Ethylene glycol & - & - & - & - & - & - & - & - & 14.00 & - \\
\hline Propylene glycol & - & - & - & - & - & - & - & - & - & 14.00 \\
\hline Egg yolk (v/v\%) & 20.00 & 20.00 & 20.00 & 20.00 & 20.00 & 20.00 & 20.00 & 20.00 & 20.00 & 20.00 \\
\hline
\end{tabular}

a) Ingredients were disolved and distilled water was added to a volume of $100 \mathrm{ml}$.

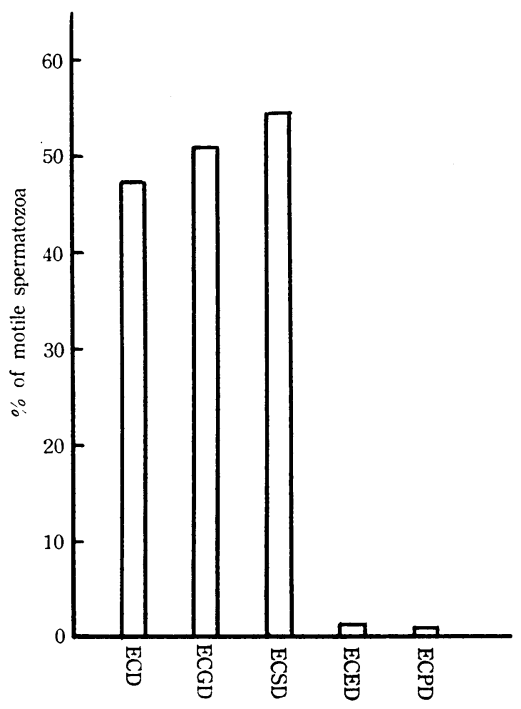

Fig. 4. Effect of diluents on the percentage of motile spermatozoa after freeze-thawing.

差のない精子生存率と活力が得られ, ECSD および ECGD ではむしろ 10 倍に比べて 20 倍のほうが良好な 精子生存性を示した。しかし ECD では前 2 者に反して 20 倍の精子生存性が 10 倍に比べてやや低下した。30 倍および 40 倍では, それぞれ漸次精子生存率の低下を 示したが，ECD を除く ECSD および ECGD では 10 倍に比べて生存率の差は僅かで有意差を認めなかった (Fig. 5)。

6. 融解温度と生存性：精子生存性に及ぼす融解温度 の影響について 検討した結果は， $5^{\circ} \mathrm{C}<10^{\circ} \mathrm{C}<15^{\circ} \mathrm{C}<$

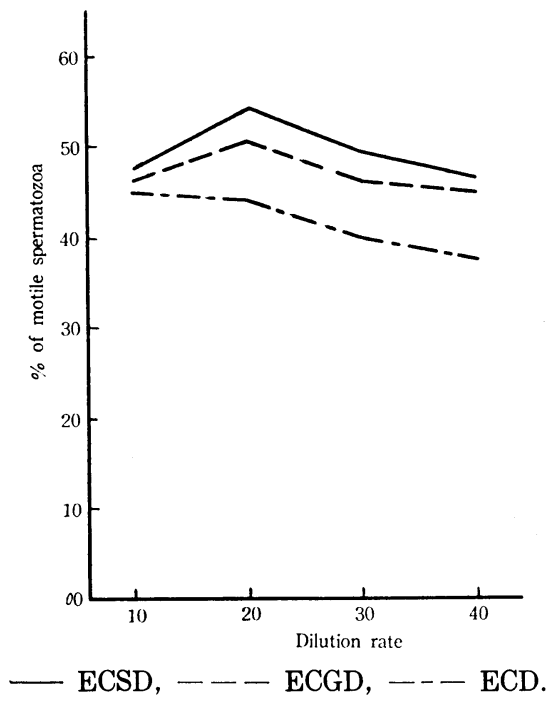

Fig. 5. Effect of dilution rate on the percentage of motile spermatozoa after freeze-thawing.

$20^{\circ} \mathrm{C}, 25^{\circ} \mathrm{C}<30^{\circ} \mathrm{C}$ の順に融解後の精子生存率が向上し, $5^{\circ} \mathrm{C}$ 融解では精子生存率の平均が $44.5 \%$ を示したもの が， $30^{\circ} \mathrm{C}$ 融解では $59.2 \%$ の生存率となり有意な差 (P. 0.01) を示した。 $30^{\circ} \mathrm{C}$ および $40^{\circ} \mathrm{C}$ 融解では両者 の生存率にほとんど差がなく, $50^{\circ} \mathrm{C}$ 融解では $40^{\circ} \mathrm{C}$ に 比べて僅かに生存率が低下したが $25^{\circ} \mathrm{C}$ 融解よりはむし ろ良好な生存率を示した (Fig. 6)。

7. 精液容器と生存性：ストロー执よびアンプルに同 一精液をそれぞれ $0.5 \mathrm{ml}$ ずつ分注して，ストローによ る急速凍結とアンプルによる緩徐凍結を比較検討した結 


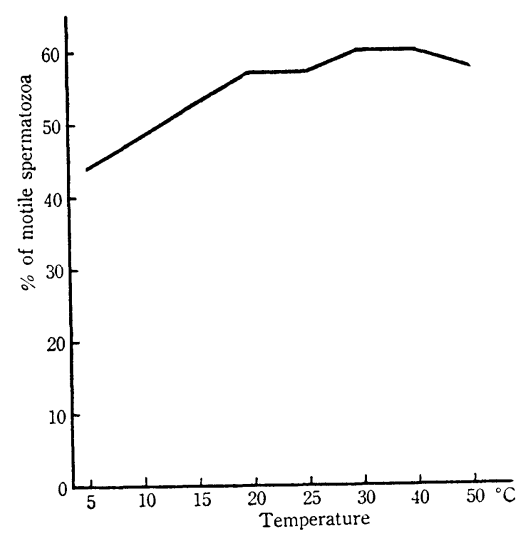

Fig. 6. Effect of thawing temperature on the percentage of motile spermatozoa after freeze-thawing.

果は，ストローを用いて急速凍結を行ったほうが凍結・ 融解後の精子生存率がやや良好であり, 山羊凍結精液で
はアンプルによる緩徐凍結とストローによる急速凍結の 両者とも利用し得ることを認めた (Table 2)。

II. 凍結精子の受胎力

1. 畜産試験場における受胎試験成績

1) 保存日数別受胎試験成績: 畜産試験場で行った受 胎試験成績を，保存日数別に表示すれば Table 3 のと おりで，1 1,022 日保存精液を 114 頭の雌山羊に 1 発 情授精を行い $71.9 \%$ の受胎率を得た。1 30 日保存精 液により $63.3 \% ， 31 １ 02$ 日保存では $79.4 \% ， 210$ 1,022 日保存では $77.4 \%$ の受胎率を得ており, 保存日 数の延長によって受胎率の低下を認めなかった（Table 3)。なお，この試験における最長保存受胎例は 1,022 日 であり, 凍結精液による産子数および性比は正常と変わ りがなかった。

2) 月別凍結精液の受胎成績：上記の受胎成績を，精 液を採取した月別に表示すれば Table 4 のとおりで, 10〜12 月の繁殖季節中に 採取した 精液と繁殖季節以降

Table 2. Effect of rapid and slow freezing on the percentage of motile spermatozoa after freeze-thawing

\begin{tabular}{|c|c|c|c|c|c|c|}
\hline \multirow{3}{*}{ Method of freezing } & \multirow{3}{*}{ No. of semen } & \multicolumn{4}{|c|}{$\%$ of motile spermatozoa } & \multirow{3}{*}{$\begin{array}{c}\text { Recovery rate } \\
(\%)\end{array}$} \\
\hline & & \multicolumn{2}{|c|}{ Pre-freezing } & \multicolumn{2}{|c|}{ Post-thawing } & \\
\hline & & Range & Average & Range & Average & \\
\hline Rapid freezing & 12 & $70 \sim 85$ & 78.4 & $45 \sim 65$ & 56.4 & 71.9 \\
\hline Slow freezing & 12 & $70 \sim 85$ & 78.4 & $30 \sim 60$ & 50.2 & 64.0 \\
\hline
\end{tabular}

Table 3. Results of conception trials with frozen semen

\begin{tabular}{ccccc}
\hline \hline Days of storage & $\begin{array}{c}\text { \% of motile } \\
\text { spermatozoa }\end{array}$ & $\begin{array}{c}\text { No. of goats } \\
\text { inseminated }\end{array}$ & $\begin{array}{c}\text { No. of goats } \\
\text { conceived }\end{array}$ & $\begin{array}{c}\text { Conception rate } \\
(\%)\end{array}$ \\
\hline $1 \sim 30$ & $30 \sim 60$ & 49 & 31 & 63.3 \\
$31 \sim 102$ & $30 \sim 55$ & 34 & 27 & 79.4 \\
$210 \sim 1,022$ & $25 \sim 40$ & 31 & 24 & 77.4 \\
Total & & 114 & 82 & 71.9 \\
\hline
\end{tabular}

Table 4. Results of conception trials with the semen frozen in different months of the year

\begin{tabular}{lccccc}
\hline \hline Month & Days of storage & $\begin{array}{c}\% \text { of motile } \\
\text { spermatozoa }\end{array}$ & $\begin{array}{c}\text { No. of goats } \\
\text { inseminated }\end{array}$ & $\begin{array}{c}\text { No. of goats } \\
\text { conceived }\end{array}$ & $\begin{array}{c}\text { Conception rate } \\
(\%)\end{array}$ \\
\hline Oct. & $1 \sim 76$ & $35 \sim 55$ & 46 & 31 & 67.4 \\
Sept. & $3 \sim 46$ & $40 \sim 60$ & 22 & 15 & 68.2 \\
Dec. & $4 \sim 1,022$ & $25 \sim 55$ & 24 & 19 & 79.2 \\
\hline Jan. & $285 \sim 715$ & $25 \sim 35$ & 6 & 4 & 66.7 \\
Feb. & $296 \sim 718$ & $25 \sim 40$ & 8 & 6 & 87.5 \\
Mar. & $235 \sim 609$ & $30 \sim 40$ & 8 & 65.0 \\
\hline
\end{tabular}


Table 5. Results of conception trials with frozen semen diluted 10 to 30 times

\begin{tabular}{cccccc}
\hline \hline Dilution rate & Days of storage & $\begin{array}{c}\text { \% of motile } \\
\text { spermatozoa }\end{array}$ & $\begin{array}{c}\text { No. of goats } \\
\text { inseminated }\end{array}$ & $\begin{array}{c}\text { No. of goats } \\
\text { conceived }\end{array}$ & $\begin{array}{c}\text { Conception rate } \\
(\%)\end{array}$ \\
\hline 10 & $2 \sim 1,022$ & $25 \sim 55$ & 88 & 62 & 70.5 \\
20 & $5 \sim 246$ & $35 \sim 60$ & 128 & 87 & 68.0 \\
30 & $1 \sim 673$ & $25 \sim 45$ & 22 & 15 & 68.2 \\
\hline
\end{tabular}

Table 6. Results of field conception trials with frozen semen

\begin{tabular}{cccccc}
\hline \hline \multirow{2}{*}{ Goat } & Dilution rate & $\begin{array}{c}\% \text { of motile } \\
\text { spermatozoa }\end{array}$ & $\begin{array}{c}\text { No. of goats } \\
\text { inseminated }\end{array}$ & $\begin{array}{c}\text { No. of goats } \\
\text { conceived }\end{array}$ & $\begin{array}{c}\text { Conception rate } \\
(\%)\end{array}$ \\
\hline \multirow{2}{*}{ G-1 } & 10 & $40 \sim 55$ & 8 & 8 & 100.0 \\
& 20 & $40 \sim 55$ & 18 & 61.1 \\
\hline \multirow{2}{*}{ G-2 } & 10 & $35 \sim 55$ & 18 & 12 & 66.7 \\
& 20 & $35 \sim 55$ & 30 & 27 & 90.0 \\
\hline \multirow{2}{*}{ G-3 } & 10 & $50 \sim 60$ & 34 & 40 & 85.3 \\
& 20 & $50 \sim 60$ & 49 & 23 & 79.3 \\
\hline G-4 & 20 & $45 \sim 60$ & 29 & 4 & 100.0 \\
\hline G-5 & 20 & 50 & 4 & 154 & 81.1 \\
\hline Total & & & 190 & & 51.6 \\
\hline
\end{tabular}

の $1 \sim 3$ 月に採取した精液とでは, 凍結精液による受胎 率にほとんど差がなく，1〜3 月に採取した精液による 凍結精液でも受胎力の低下しないことを認めた（Table 4)。

3）希釈倍率別の受胎成績：精液の希釈倍率別による 受胎成績は Table 5 のとおりで， 1 発情授精において， 10 倍希釈精液では計 88 頭の授精により受胎率 $70.5 \%$ を得，20 倍および 30 倍希积精液では，それぞれ 128 頭および 22 頭の授精により $68.0 \% ， 68.2 \%$ の受胎率 を得た。以上の受胎成績から，10〜30 倍の希釈は受胎 率に与える影響において有意差を認めず，良好な受胎成 績を得ることを認めた (Table 5)。

\section{2. 群馬県における野外受胎試験成績}

群馬県畜産試験場での採取精液を, 当場（農林省畜 試，千葉）へ輸送し凍結した精液を用いて, 群馬県畜産 試験場で実施した野外受胎試験成績を, 種雄山羊別, 希 釈倍率別に表示すると Table 6 のとおりである。なお この試験では 4〜 49 日保存の凍結精液を用いた。

1 発情の授精により, Table 6 に示したように，5頭 の雄山羊別の受胎率は $61.1 \sim 100.0 \%$ で良好な受胎成 績を得た。10 倍および 20 倍の希釈倍率別の受胎成績 では,それぞれ 60 頭および 130 頭の授精によって $81.7 \%, 80.8 \%$ の受胎率を得，10２0 倍希釈では希釈
倍率による影響を受けないことを認めた。この野外試験 では，10〜20 倍， 4〜49 日保存精液を用いて，計 190 頭の雌山羊に 授精した結果， $81.1 \%$ の良好な受胎率を 得た (Table 6)。

なお，山羊凍結精子は融解後 $4 \sim 5^{\circ} \mathrm{C}$ に保存すると, 比較的急速に生存性が低下し，個体によっては融解後に 希釈精液の凝固が速く生じるものがあるので，融解した 精液は直ちに授精することが必要である。

\section{考察}

山羊凍結精子の精子生存性に影響を及ぼす各種要因と して，希釈液中の卵黄量およびグリセリン濃度を検討し

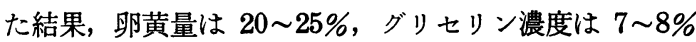
が凍結・融解後の精子生存に良好な影響を与えることを 認めた。SAROFF \& MIXNER ${ }^{8)}$ は牛凍結精液において, 希釈液中の卵黄量とグリセリン濃度との関係について検 討し，ECDに称いて即黄量 20\%，グリセリン 7\%（最 終濃度) のときに好結果を得ている。そのほか牛精液の 凍結において ECD 中の卵黄量およびグリセリン濃度 は，それぞれ 20〜25\% および 7\%（最終濃度）を最適 範囲とするもの (KINNEY \& VANDEMARK ${ }^{9)}$, BRATTON

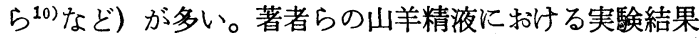
も, SAROFF \& MIXNER らの報告と同じ傾向を示してい 
1977 年 12 月

る。グリセリン平衡についての実験では，6〜18 時間の 平衡時間において凍結後良好な精子生存率を得たが，こ れは MILLER \& VANDEMARK ${ }^{11)}$ および SUlLIVAN \& MIXNER ${ }^{12)}$ らの牛凍結精液の成績と同じ傾向を示すもの であり, また SULLIVAN \& MIXNER は, 融解後の精子 代謝能において 6 18 時間のグリセりン平衡の間にほと んど差が無く, 他の平衡時間より優る値を示したことを 報告している。FRASER ${ }^{13)}$ は山羊精液の凍結において, 脱脂乳にグリセリンを添加した希釈液を用いて 10 分〜 24 時間のグリセリン平衡時間について検討し，8 24 時 間の平衡時間において最も良好な結果を得たことを報告 しているが著者らの成績と同じ傾向といえる。山羊精液 では, 精漿中の酵素の作用により, 希釈精液中の卵黄の 凝固之酸の生成により精子が死隇する特異な現象を有 し ${ }^{14)}$, 個体によっては相当に早く凝固の出現するものが あるので, 短時間のグリセリン平衡で涷結するほうが良 く, 6 8 時間程度のグリセリン平衡で凍結を開始する ことが望ましい。希釈液の種類と凍結後の精子生存性に ついての検討では，ECD に比べて ECGD および ECSD による希釈精液が，凍結後の精子生存性に有効に作用し たが，希釈液に含有された糖による精子代謝への影響お よび凍結過程における塩害の緩和などが有効に作用する とともに，ECSD ではさらにクロルプロマジンによる精 子代謝への影響などが有効に作用しているものと推定さ れる。なお ECED, ECPD のエチレングリコールおよ びプロピレングリコールは, 山羊精液の涷結に対して全 く有効に作用せず, 抗凍結物質としてのグリセリンの有 効性が山羊精液において子確認された。希釈倍率と凍結 精子の生存性では，10３0 倍において凍結後の精子生 存性に大差がなく良好な結果を得た。牛精液においても 10 30 倍希釈精液の凍結が 実用的に行われており，山 羊精液においても同じ傾向を有することを認めた。融解 温度と精子の生存性では, $5^{\circ} \mathrm{C}$ 融解上り $40^{\circ} \mathrm{C}$ 融解に至 るに従い精子生存率が向上したが，牛精液においても

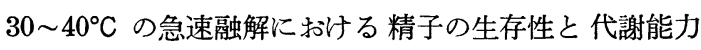
が， $5^{\circ} \mathrm{C}$ 融解のものよりもまさることを, 枅田および和 出 ${ }^{15)}$ が報告している。 $0.5 \mathrm{ml}$ ストローと液体窒素によ る急速凍結精液の精子生存性は, アンプルによる緩徐凍 結精液の精子生存性に比べややまさることを認めたが, 牛凍結精液においても同じ傾向が認められ，また和出 $ら^{18)}$ とよる豚凍結精液の実験においても，急速凍結は緩 徐凍結よりも凍結後の精子生存性に有効に作用すること が認められている。山羊精液においてもこれらと同じ傾 向を示すものといえる。
家畜繁殖誌 23 巻 4 号

初期の研究における山羊凍結精液の受胎力は低く, LIESS \& OSTROWSKI ${ }^{1)}$ は山羊の凍結精液を 90 頭の雌山 羊に授精し, $13.3 \%$ の低い受胎率を得たことを報告して いる。著者らは特殊な緬・山羊用の子宮頸管鉗子と頸管 深部注入用の注入ピペットを考案して, 緬・山羊では従 来行われていなかった頸管内深部注入を可能とし, 山羊 凍結精液による受胎率の向上をはかった。著者らの子宮 頸管内深部注入法による山羊凍結精液の受胎試験では, 1 1,022 日保存精子を雌山羊の授精適期に 1 発情 1 回 注入する方法により 114 頭に授精した結果，1発情授精 により $71.9 \%$ の良好な受胎率を得た。WAIDE \& NIWA ${ }^{4)}$ は 1961 年に頸管内深部注入法によって凍結精液を 84 頭の雌山羊に授精し，1 発情授精によって 70.2\% の受 胎率を得ているが，GOFFAUX \& CORTEEL ${ }^{17)}$ は緩徐凍 結に上る活力良好な山羊凍結精液を 168 頭の雌山羊に 1 $\mathrm{m} l$ ずつ注入した結果, 25 頭が受胎して低い受胎率を 得, BONFERT ${ }^{18)}$ は 885 頭, 666 頭および 601 頭の雌山 羊に凍結精液を授精し $65.0 \% ， 64.7 \%$ 打よび $66.6 \%$ の NR 率を得, CORTEEL ${ }^{18)}$ らは凍結精液による繁殖季 節中の授精で $56.8 \%$ の受胎率を得ている。最近 GONZALEZ $^{20)}$ は液体窒素により $0.5 \mathrm{ml}$ ストローで涷結 した山羊精液を 35 頭の雌山羊に頸管内注入により授精 し，初回授精に执いて受胎率 $68.6 \%$ を得たことを報告 している。

著者らは山羊の繁殖季節である 10 12 月以降の非繁 殖季節である 1 3 月に採取した精液を凍結保存し，同 年の $10 \sim 12$ 月に 22 頭の雌山羊に授精した結果， 1 発 情授精により $77.2 \%$ の良好な受胎率を得たが，繁殖季 節外の従来繁殖に供用していない時期の精液を採取して 凍結・保管することにより，優良山羊の効率的利用を一 層拡大し得ることを確認した。精液希釈倍率と凍結精液 の受胎力についての検討では, 10 30 倍希釈の凍結精 液により 1 発情授精で 68.0 70.5\% の良好な受胎率を 得た。液状精液では 10 倍以上の高倍率希积になると, 精子生存性が漸次低下して有効保存日数が 短縮される が, 凍結精液では長期保存が可能であり, 山羊精液のよ らに精液量の少量なものにおいても, 高倍率希釈精液を 凍結保存することにより極めて効率的に精液を利用し得 ることが確認された。

群馬県畜産試験場の雄山羊の精液を第 1 次希釈後に農 林省畜産試験場へ輸送して凍結し, 群馬県畜試へ再輸送 した凍結精液による野外受胎試験では，5頭の雄山羊別 の受胎成績㧍よび 10 倍, 20 倍の希釈倍率別の受胎成 績において，いずれも良好な結果を示し，計 190 頭の 1 
1977 年 12 月

発情授精により $81.1 \%$ の受胎率を得た。この結果か ら, 凍結精液の輸送と組織化による広域利用が山羊にお いても可能なことが確認された。

\section{要 約}

山羊精液の保存について, 凍結精子の生存性に及ぼす 各種の要因および保存精子の受胎能力についての実験結 果から次の所見を得た。

1. 精液の希釈に使用する卵黄クエン酸ナトリウム液 中の最適卵黄量は $20 \%$ である。

2. $20 \%$ の卵黄を含有した卵黄クエン酸ナトリウム 液中のグリセリン濃度（B液）は，14 16\%（希釈精液 中の最終濃度は 7〜8\%) である。

3. グリセリン平衡時間と凍結精子の生存性との関係 は, 3〜24 時間の間に大差がなく，6〜18 時間において 最も良好な生存性を示した。このことは，希釈精液中の 卵黄を凝固させる作用が強い個体の精液では， 6 8 時 間程度の短時間のグリセリン平衡において凍結するほう が好結果を得ることを示唆しており, 山羊精液の凍結保 存における特殊性といえる。

4. 希釈液の種類と精子生存性の関係についての検討 では, 著者らの開発した ECSD が凍結後の精子生存性 に良好な影響を与え, ついで ECGD が良好であった。 エチレングリコール, プロピレングリコールの使用は精 子生存性を著しく低下させた。

5. 希釈倍率と精子生存性の関係では, 10 30 倍希 釈は精子の生存性に悪影響がなく，実用的に利用しうる 範囲の生存性を示すことを認めた。

6. 融解温度と精子生存性の関係では $30 \sim 40^{\circ} \mathrm{C}$ の融 解が最も良好な精子生存性を示したが, 受胎試験は $20^{\circ} \mathrm{C}$ 融解で行った。融解後の精子生存性は, 山羊では 比較的急速に生存性が低下し, 個体により融解後に希釈 精液の㠜固を速く生ずるものがあるので, 融解後は直ち に使用することが必要である。

7. 頸管内深部注入法による受胎成績は, 農林省畜産 試験場における試験では，1１,022 日保存の凍結精液 により計 114 頭の授精を行い， 1 回授精で $71.9 \%$ の受 胎率が得られた。またとくに保存日数別に受胎率の差は 認められず，最長保存受胎例は 1,022 日であった。10〜 12 月のいわゆる 繁殖季節と, 季節外の $1 \sim 3$ 月に採取 した精液の凍結精子とでは, 特に受胎力に差が認められ ず， 1 3 月に护ける季節外精液の 凍結保存による利用
家畜繁殖誌 23 巻 4 号

が示唆された。

群馬県下で実施した野外受胎試験では，10２0 倍希 釈の凍結精液により計 190 頭を授精し， 1 回授精で 81.1\% の高い受胎率が得られ，10 倍希釈では 49/60, $81.7 \% ， 20$ 倍希釈では 105/130，80.8\% の受胎成績を 示し，両者に差のないことを認めた。

おわりにこご校閲をいただいた当場繁殖部長渋谷祐彦 博土に深謝いたします。また授精試験にご協力いただい た群馬県畜産試験場の関係者各位に感謝いたします。

(1977.1.10 受付)

\section{文献}

1) Liess, J. \& J. E. B., Ostrowski: Dtsch. tierärztl. Wschr. 67, 127, 1960.

2）和出 (靖) - 大槻 (清) - 丹羽 (太) : 日畜会報 30 別 号, 4, 1959 (Abstr.).

3) 和出 (靖) - 丹羽 (太) - 白井 (節)：日畜会報 31 別 号, 46, 1960 (Abstr.).

4) Waide, Y. \& T. Niwa: VIIIth. Int. Congr. Anim. Prod. Hamburg I, 183, 1961.

5) Fraser, A.F.: Canad. Vet. J. 3, 133, 1962.

6) Vlachos, K. \& P. Tsaklov: Geoponika, Period. $B^{\prime}$ 10, 57, 1964.

7) Bonfert, A.: VI ${ }^{\ominus}$. Cong. Int. Reprod. Anim. Insem. Artif. Paris. II, 1613, 1968.

8) Saroff, J. \& J.P. Mixner: J. Dairy Sci. 38, 292, 1955.

9) Kinney, W.C. \& N.L. VanDemark: J. Dairy Sci. 37, 650, 1954.

10) Bratton, R.W., R.H. Foote \& J.C. Cruthers: J. Dairy Sci. 38, 40, 1955.

11) Miller, W.J. \& N.L. VanDemark: J. Dairy Sci. 37, 45, 1954.

12) Sullivan, J.J. \& J.P. Mixner: J. Dairy Sci. 46, 463, 1963.

13) Fraser, A.F.: Canad. Vet. J. 3, 133, 1962.

14） 入谷(明) - 西川(義)：本誌 $8,109,1963$.

15）枡田 (博) - 和出 (靖)：畜試研報 (24), 13, 1971.

16）和出 (靖) - 副島 (昭) - 枡田 (博)：凍結精液研究会 報 (27), 10, 1969 .

17) Goffaux, M. \& J.M. CoRteel: Annls Zootech. 16, 213, 1967.

18) Bonfert, A.: VI ${ }^{e}$. Cong. Int. Reprod. Anim. Insem. Artif. Paris, II., 1613, 1968.

19) Corteel, J. M., M. Courot \& R. Ortavant: VII. Int. Cong. Anim. Reprod. A.I. München 187, 1972.

20) Gonzalez, S.G.: Zootechnia 24, 151, 1975. 


\section{Summary}

This experiment was conducted to examine motility and fertility of goat spermatozoa which were frozen slowly in dry ice and alcohol and rapidly in liquid nitrogen vapor using ampoule and plastic straw. Semen was collected from 4 Sannen goats. The semen was diluted at the rate of 1 part of the semen to 4 of the first diluent ECSD (A) at $25 \sim 27^{\circ} \mathrm{C}$, which did not contain glycerol. The diluted semen was cooled to $4^{\circ} \mathrm{C}$ over a period of 1 hour and was kept for $2 \sim 3$ hours at $4^{\circ} \mathrm{C}$. The semen was rediluted at the rate of 1 part of the semen to $0 \sim 3$ of the first diluent at $4^{\circ} \mathrm{C}$. Then, the second diluent ECSD (B) containing 14\% of glycerol (v/v) was added to the first or the rediluted semen at the rate of $1: 1$ four times at 15 minutes interval. The diluted semen was allowed to equilibrate at $4^{\circ} \mathrm{C}$ for $6 \sim 18$ hours before freezing. Each $0.5 \mathrm{ml}$ of the equilibrated semen was placed into the ampoule or plastic straw. One of the equilibrated semen samples was cooled gradually from $5^{\circ} \mathrm{C}$ to $-15^{\circ} \mathrm{C}$ at $1 \sim 2^{\circ} \mathrm{C}$ per minute, $-15^{\circ} \mathrm{C}$ to $-30^{\circ} \mathrm{C}$ at $4 \sim 5^{\circ} \mathrm{C}$ per minute and $-30^{\circ} \mathrm{C}$ to $-75^{\circ} \mathrm{C}$ at $3 \sim 4^{\circ} \mathrm{C}$ per minute with dry ice and alcohol, then stored at $-79^{\circ} \mathrm{C}$. The other samples were cooled rapidly from $5^{\circ} \mathrm{C}$ to $-100^{\circ} \mathrm{C}$ in liquid nitrogen vapor for 4 to 5 minutes and stored at $-196^{\circ} \mathrm{C}$ in liquid nitrogen. The motility of spermatozoa before and after freezing was examined. The fertility of frozen spermatozoa was also tested. Insemination was performed by the deep cervical method with forceps and a pipette specially designed for goats and sheep. Volume of the semen was $0.5 \mathrm{~m} l$ per insemination, and the dilution rate was 10 to 30 times. The semen was thawed before insemination at $20^{\circ} \mathrm{C}$.

The results obtained are as follows.

1. The optimum amount of egg yolk in the diluent was 20\% (3\% sodium citrate solution 4: egg yolk 1), and that of glycerol in the second diluent was 14 to $16 \%$.

2. Effect of different glycerol equilibration time, 1.5 to 48 hours on motility of frozen spermatozoa was examined. The semen equilibrated for 6 to 18 hours gave good motility and high percentage of motile spermatozoa after thawing.

3. Good motility and high percentage of motile spermatozoa after thawing were obtained when a specially prepared diluent ECSD was used for goat semen. When ethylene glycol or propylene glycol was used instead of glycerol, the viability of spermatozoa decreased markdly.

4. Motility of spermatozoa was best when the semen was thawed at $30^{\circ} \mathrm{C} \sim 40^{\circ} \mathrm{C}$. However, in conception trials, satisfactory results were obtained with semen thawed at $20^{\circ} \mathrm{C}$.

5. Effect of different dilution rates, 10 to 40 times, on motility of frozen spermatozoa was examined. Motility of spermatoza after thawing was generally good when it was diluted 10 to 20 times, but it was gradually decreased when it was diluted more than 20 times.

6. The dilution rate of the semen used for conception trials was 10 to 30 times. The frozen goat semen was stored at $-79^{\circ} \mathrm{C}$ or $-196^{\circ} \mathrm{C}$ for 1 to 1,022 days. Each $0.5 \mathrm{ml}$ of the semen was inseminated by deep-cervical method using forceps and a specially devised insemination pipette. All inseminations resulted in good conception rate, $71.9 \%$ for 114 goats with the semen from 15 male goats stored for $1 \sim 1,022$ days.

The longest record of storage of frozen goat semen with satisfactory conception was 1,022 days. The conception rate from the field conception trials with the semen from 5 other male goats stored for not longer than 2 months was $81.8 \%$ (154/190) after single insemination. 